\title{
PIK3CA Gene Amplification
}

National Cancer Institute

\section{Source}

National Cancer Institute. PIK3CA Gene Amplification. NCI Thesaurus. Code C96864.

A molecular genetic abnormality indicating the presence of multiple copies of the PIK3CA

(phosphatidyl inositol 3-kinase) gene. 